\title{
The dialectics of new fascism in Greece
}

\author{
A dialética do novo fascismo na Grécia
}

\author{
Athanassios MARVAKIS
}

\begin{abstract}
The success of historical fascism in the particular transitional period at the beginning of the $20^{\text {th }}$ century was grounded in its contribution to the successive acceptance and application of the so-called Fordist model for the organization of labor (accompanied by the correspondent social conditions and relations). Historical fascism contributed thus, with its particular way, to establishing a new class compromise between the potentials related with the productive forces and the confinements emanating from the productive relations. This contribution constitutes the "creativity" of fascism. Such a historical perspective on social processes allows us not to fall into the trap of understanding fascism only as a (barbarian) "deception". Fascism cannot be a plain deception, because a "mere deceit" cannot mobilize people. Fascism takes over, adopts real and unfulfilled needs and hopes - which as such constitute resistance to the capitalist arrogance and logic of commodification of everything - and offers its own (fascist, barbarian) solution or fulfillment. Consequently, our responsibility cannot lie in rejecting these needs and hopes (which are basically needs and hopes for security) because of their distorted or "pervert" articulations. Our responsibility lies in the careful peeling of these hopes/demands from their (fascist) enwrapment. Nationalism (from the subalterns!) does not constitute a mere irrational leftover from the past, but contains potentially mystic and romantic pre- or anti-capitalist elements and references. Nationalism obtains its dynamics and persuasion (for the subalterns!) from and for the contemporary societal processes, thus constituting an active, political and actual demand/position within the restructuring of society - which is in itself a moment in the restructuring of capitalism. Herein also the "rational kernel" of the anti-capitalist antithesis by the New Right is founded as counter position to the "neutral" commodification of everything. This antithesis can of course not be the issue for us the opponents of fascism. The "problem" for us is the fascist perspective in which this antithesis is embedded; the political vision which has recruited the antithesis for confining solidarity only to "our people" and not broadening solidarity towards all people!
\end{abstract}

Keywords: Ernst Bloch; Fascism; Greece; Nationalism; New right; Social consciousness; Solidarity.

\section{Resumo}

O sucesso do fascismo histórico no período de transição, em particular no início do século 20, foi baseado em sua contribuição para a aceitação e aplicação sucessiva do chamado modelo fordista para a organização do trabalho (acompanhada das condições e relações sociais correspondentes). Fascismo histórico contribuiu assim, em sua forma particular, com a criação de um novo compromisso de classe entre os potenciais relacionados com as forças produtivas e as prisões que emanam das relações produtivas. Esta contribuição constitui a "criatividade" do fascismo. Tal perspectiva histórica sobre os processos sociais, não nos permite cair na armadilha de se compreender o fascismo apenas como

\footnotetext{
$\boldsymbol{\nabla} \nabla \mathbf{v}$
}

1 Aristotle University of Thessaloniki, Department of Primary Education. University Campus, Building "Tower", 54124, Thessaloniki, Greece. E-mail: <marvakis@eled.auth.gr>

All the quotes are from Ernst Bloch's book Erbschaft dieser Zeit (first published 1935; here quoted from the 1985 edition). 
um (bárbaro) "engano". O fascismo não pode ser um engano simples, porque um "mero engano" não pode mobilizar as pessoas. Fascismo assume, adota necessidades e esperanças reais e não cumpridas - que, como tal, constituem resistência à arrogância capitalista e lógica da mercantilização de tudo -, e oferece a sua própria solução (fascista, bárbara) ou sua realização. Por conseguinte, a nossa responsabilidade não pode mentir em rejeitar essas necessidades e esperanças (que são, basicamente, precisas e esperar pela segurança) por causa de suas articulações distorcidas ou "pervertido". Nossa responsabilidade exige-nos cuidadosas esperanças e demandas de seu (fascista) envolvimento. Nacionalismo (a partir dos subalternos!) não constitui uma mera sobra irracional do passado, mas contém potencialmente elementos anticapitalistas e referencias pré-místicas e românticas. Nacionalismo obtém sua dinâmica e persuasão (para os subalternos!) de e para os processos sociais contemporâneos, constituindo, assim, uma demanda/posição ativa, politica e real no âmbito da reestruturação da sociedade - que é em si mesmo um momento na reestruturação do capitalismo. Aqui também o "núcleo racional" da antítese anticapitalista pela Nova Direita é fundada como posição contrária à mercantilização "neutra" de tudo. Esta antitese pode, naturalmente, não ser o problema para nós, os adversários do fascismo. O "problema" para nós é a perspectiva fascista em que essa antítese é incorporada; a visão política que recrutou a antítese para confinar solidariedade apenas para "nossa gente" e não a ampliação de solidariedade para com todas as pessoas!

Palavras-chave: Ernst Bloch; Fascismo; Grécia; Nova direita; Nacionalismo; Consciência social; Solidariedade.

\section{Bitter occasion}

A personal-political "distress" has been - as a bitter occasion - the spur for the beginning of this short reflection about the momentum acquired by the New Right in Greece (as elsewhere), as well as about the position and politics of the left in front of this dynamic. The incident, which will be immediately described, appears to me to encapsulate the rumination of a whole era, and the problematic character of the political movements in this era.

It was in autumn of 2007, a short time after the parliamentary elections, when, in the first meetings of the Greek Parliament, different Member of Parliament (MP) were stepping on the podium to present for the first time their views and stances. My original and ingenious joy and stir for the fact that a deaf MP, Dimitra Arapoglou, stepped on the podium was partially overshadowed after the appearance on the TV screen of the caption mentioning the political party as a representative of which she was standing there: this was the Popular Orthodox Rally (LA.O.S) - and not some party of the Left! My stir and joy were transformed in a sort of distress, which I tried to deal with and divert by wondering: "how is it possible" - not the election of a deaf woman MP by the New Right, but "how is it possible for the Left to not have a deaf woman as a candidate!?".

The right wing bloc, the par excellence basis

548 of which is the limitation of social solidarity to only those that it considers "its own people", is the one which, by means of a gesture like that, makes a practical pronouncement of solidarity as one of its significant political values - possibly only on a rhetoric level or for the purpose of deceit. Whichever of these two possibilities is finally nearer to reality, this move in itself puts the social issue high on the agenda - though from a right wing perspective! With this move, this specific bloc of the New Right has managed to not only steal the show from the Left, but also to seize one of the central one of the central themes of the Left: Social solidarity!

We are in a position, I believe, to agree that the invitation extended by the president of the left party "Synaspismos", Alexis Tsipras, to Kanditsa Sanko, an offspring of immigrants from Sierra Leone, to accompany him in the official reception of the President of the Republic of Greece for the reinstitution of Democracy in the country after the collapse of the military dictatorship was a good, and yet momentary, political move of a vibrant Left. Under the same reasoning, the extension of an invitation to a person such as the deaf female MP would be a good long-term political move, one which would simultaneously make a statement with regards to the "natural" place of the Left in our society, in terms of its closeness to particular social groups of people.

I am not able (that is, I refuse!) to imagine that there are no suitable persons from within the ranks of the Left that would accept the invitation 
to step on the Parliament's podium. Provided, of course, that nobody would demand from them to first acquire, in any possible way, an intra-party power so great as to secure - ultimately take away from the senior, older, more powerful - an eligible position. In the context of this sort of cooperation, these new MP would, on the one hand, do good with regard to issues that relate to the living conditions of the social groups they belong to, and, simultaneously, on the other, call to mind that which is the historical place of the Left in our society: the factual and reliable treatment of the social issue from a left perspective. This means, of course, nothing less than the treatment of the social issue with the prospect of broadening the social solidarity and not limiting it to those who are viewed at each different time as "our own people".

Be careful, though: the emerging New Right with which we are actually confronted today, as the new-fashioned political "material"/movement for the new fascism that is being shaped, has taken its "seminars" all over Europe. It has taken, that is, its historical lessons - with its thugs appearing now to be knowledgeable and, up to a certain point, "contained". In other words, we ought to be careful: the new fascism is not the same with the neo-fascism of the postwar period - though often it is exactly the same persons that are representing it!

Before continuing, however, it is worth remembering, at this point, some political elements/ characteristics of the New Right, which is the protoplasm of the new fascism:

a) A radical nationalism constitutes the cornerstone of the New Right, including the ideological claim for a homogenized uniformity, from which it is also apparently resulting/inferred the rejection of difference. This is, of course, a characteristic in which the emphasis on the nation is also partially signifying a sort of a "conceptual modernization" of the new fascism, the replacement, that is, of the concept "people" by that of "nation".

b) An anti-systemic element - not in the form of a general de-legitimization of the democratic polity ("all politicians are the same"), but in the logic of "all others (essentially the elite) are not adequately capable/clean for the system to work".

c) A difficult political marriage, between, on the one hand, support for neo-liberal (economic) policies, and on the other, the claim/demand for "national preference". This marriage produces an internal tension which has found in Greece too, as all over in Europe, the par excellence field for its release and pursuance in a plethora of policies at the expense of immigrants! For example: while the party of Popular Orthodox Rally (LA.O.S) is not totally opposed to the existence of immigrants in our country, it "straightforwardly" demands a brute utilitarian regulation regarding their stay (the important and politically dangerous fact here being its sharing this demand with a sweeping political spectrum!).

d) Effort towards a massive mobilization based on, for example, (common) experience, a feeling of subjective vulnerability and exposition to incompetent elites and to forces that are not being controlled (though they could be). Or based, for example, on the experience/feeling of injustice, lack of decent treatment (see also the catchphrase of LA.O.S: "they are stealing our jobs, they are stealing our dignity").

\section{Fascism and the Left in a "transition era"}

I am convinced that we are able, and have a lot to learn from the discussions of the historical antifascist struggle to the benefit of the ideological and political fights in which we are already actively involved, as well as to the benefit of those that will reach a further climax in the future. The phrase "to learn" has its double meaning: (a) to learn from the depths of the historical understanding and analysis, and (b) to learn from the mistakes of the struggle. (Allow me to say as a parenthesis: the lessons gained from the historical antifascism are also useful for the antiracist movements!).

A prerequisite to learn from the historical antifascist struggle consists in the process of historicization. That is, in the incorporation of both the development of fascism and the resistance to it in the more general societal processes at each 
historical era. In this way we can understand that as the era of the historical fascism was characterized by immense changes in the way societies were organized and (re)produced (which have become known by means of the concept suggested by Gramsci: Fordism), in our days, too, we are in a similar transition period, a period where a corresponding, neo-liberal, radical transformation of our societies is being prepared, if not already materialized.

The crisis that pervaded the era of the historical fascism, and the respective crisis that pervades our own era, was/is a global one, in the sense that it has to do with the all-embracing, radical (re)organization of societies and not merely with the (social or cynical) "management of budgets". In other words, it has to do with "intensely political" processes, exactly because they concern the "substantial" and not only the "administrative" aspects of political action. They also concern, that is, the question of "where we are going" as society, and not only that of "how we will get there". Apart from their code word as post-fordist, the upheavals of the contemporary transformation reposition and concern the central coordinates of our societies, as, for example, the model of "individual"/"subject", the models of social relations, the organization of societies, the relationships among social groups and individuals, etc. As we can see, both in the beginnings of the $20^{\text {th }}$ century as well as now, the conflicts or/and negotiations concern and aim to a historical (and class) compromise between (the capacities of) the productive forces and (the limitations of) the productive conditions/relations. That is, our transitional era carries within it a new historical compromise, one that concerns the "what" and "how" of our society's future.

In such a "critical" societal landscape, fascism does not constitute merely the "fulfillment" of the one, single logic of capitalism or the unfolding/climax of the negative/controversial aspect of Modernism. In other words, fascism does not constitute the inescapable outcome of capitalism (at the imperialist stage), or its (conspiratorial!?) imposition by monopoly capital.
And it does not constitute at all a useful and brutal joker of capital.

Much more fruitful is the understanding or the conceptualization of fascism's "creativity" not as a value system, but as a political movement; the understanding, that is, of its flexibility for political "synthesis". Fascism's ability to politically synthesize socially contradictious groups, to tie together contradictory economic interests, and to organize a massive movement, points out, demonstrates to us the need to avoid a unidimensional understanding. And this is in contradistinction to the dominant views that see it simply and merely either as a teleological outcome (or/and conspiratorial imposition), either as anthropological/cultural "degradation". (Simplistic views which essentially transubstantiate and project their own inability to apprehend the controversial movement of society to the simplicity of what constitutes the subject matter as such that they are trying to study).

The success of the historical fascism in its specific "transitional era" is based on its contribution to the gradual acceptance and implementation of the 'so called' fordist model of labour organization (accompanied by relevant social relations and conditions). This success points to at least one important issue: through the synthesis of contradictory elements and the massive movement for its support, fascism contributed to the organizational solution of the question of the (re)organization of labour. It contributed, that is, in with a very particular way to the attainment of the new (at the time) (class) compromise between the possibilities that were being opened by the development of the productive forces and the constraints that were originating from the productive relations. The creativity of fascism consisted exactly in its aforementioned contribution.

Some of the questions posed here for all of us are: Can we identify commensurate changes in the organization of labour and of the societal conditions and relations in our historical era? What controversial perspectives can we identify with respect to the reorganization of our societies? Which is the potential contribution of the new fascism to the marking out and materializing 
"modern compromises", in the sense of the reorganization of the societal processes in our era?

In this new, under configuration, and "critical" societal field of multifaceted controversies there also takes place anew the specification of the character of the political forces: Here, the historical glance is useful because it urges us to determine anew what is "hell" and what is "paradise" in each historical epoch. And in this way, fascism too ceases to appear (or to be spotlighted?) as a metaphysical monster outside the social space and time. Consequently, it becomes possible for its political power to be marked out, a power that is itself based on a certain social dynamic, that is successful in (co)enlisting too many and different subjects under one political premise, together with their variform and controversial goals.

This historicization necessitates also the reassessment of the Left and of its responsibility in the specific era: not so much in relation to its general goals - these remain (unfortunately) the same (and they are in principle defensive), but more with regards to which social and political subjects ("components") are going to constitute (to "take charge" - and not only "represent") the Left as a social and as a political movement: which social groups will the Left "take side" with, which social groups it can "accommodate", to which social groups it will be giving space and to which it will not! (And it is exactly this point where the instance with the deaf female MP of LA.O.S - and not of the Left - refers to).

To put it more provocatively: here, the success of the Left is going to be measured/assessed on the basis of whether and to what extent it can hinder, deter, or even defeat the new fascism. It is this historical responsibility that essentially "legitimizes" the necessity for the existence of a Left, rather than some metaphysical logic. The percentage of people listening to Theodorakis' music or the frequency with which his songs are played in the different radio channels does not constitute an indicator of the success of the Left, neither does the percentage of its followers who belong in the higher social strata or/and occupy powerful positions in the country's authority structure, thus being "successful citizens".

\section{Social consciousness and dynamics of fascism}

Another question we have to ask ourselves in order to understand the social dynamics of the (new) fascism is that of its "attraction": "Why do subject follow it, why are they "persuaded?" "Could it be that they are deceived?".

Let us begin from our common suppositions: every social formation, every society, is not pervaded by only one - let that be dominant - mode of production and its one and only "logic" in accordance with which people act. Such a thing cannot even happen in our deepest dreams. Therefore, social/political consciousness is not something that can be specified univocally on the basis of one and only logic - even if this is a dominant one! (moreover, what is the usefulness of distinguishing a "dominant" mode of production and a "dominant" logic, when there is not at least one other - subordinate - mode of production with its corresponding logic?) Accordingly, the social/ political practice of a subject could also not be "synchronized" with one and only logic, but, rather, it is a practical synthesis of more, and possibly controversial, logics. The subject has to find, and does find, ways to incorporate their uniform social consciousness the different requirements and exhortations that are based in the coexistence of more than one and different modes of production in each society.

It is, therefore, reasonable that the reference to, the analysis, or the invocation of one - even if dominant - logic, and of the mode of production from which this logic acquires its "enticement", cannot "cover" completely the social/political consciousness and practice of any subject. As a consequence, both the political propositions and the projects that summon the subjects to action do not (cannot) invoke or make reference to only one - even if dominant - logic for the political consciousness and action of the subjects without 
mechanistically limiting, at the same time, its multidimensional character.

If we follow this rationale, we will soon agree, I believe, that in each particular society the social/political consciousness on which human action is based is not formed in a unidimentional manner, possibly as an "imposition" of the logic of the dominant mode of production; on the basis of the "capitalist rationality" and the "transformation of everything into commodities", for example, in our historical era. Thus, we will easily agree I think that there are (there must be) other "good reasons" too that motivate people and their action, reasons that do not follow the logic(s) that underlie the capitalist mode of production.

The composite and multidimensional formation of social consciousness compels the political forces that want to rely on massive movements to acknowledge, take into account its aforementioned characteristic. For this reason, fascism too - as a powerful and (at least historically) successful political movement - must be granted the acknowledgement of its creativity in this respect, and we should therefore search at each time the composite elements used by the political movements to address our social consciousness.

Such acknowledgement of the political creativity of fascism offers us also the potential to keep the mirror up against our own political practices, in order to also see in this way the gaps in the analysis and the politics of the workers' movement of the left. With regards to this, the account by the German philosopher Ernst Bloch (1935/1985) of the historical fascism still sounds as extremely timely and useful: "The Nazi speak deceivingly, but to people, the Communists absolutely truthfully, but only about things" 2.

Ernst Bloch tried to understand fascism (the german Nazism, in particular) not only as "collateral damage" and/or as an imposition by monopoly capital, but he also searched for the "synthesizing" elements that allowed fascism to organize a massive movement that included various - and contradictory in terms of their "interests" - social subjects. (The fact that a deaf female MP found political shelter and platform in a party like LA.O.S is a result of this kind of "political creativity", given that the strategic aim of this party is anything but "to universalize solidarity" in terms of extending it to an always larger number of people - including also the socially excluded).

Ernst Bloch tried also to identify the void point of the Left, its weaknesses that finally contributed to the disastrous defeat of the workers' movement in its historical "task" - that of averting the ferocity o Nazism. The analyses made and the evidence provided by the workers' movement about Hitlerism were anything but wrong. As Bloch stresses with emphasis, the "mistake" was not in what it did (e.g., the communist party) but exactly in what it did not: "... what the Party did before Hitler's victory was absolutely correct, but what it did not do, that was the mistake" ${ }^{3}$.

A gap, an omission in the politics of the Left was/is possibly its own limitation, its concentration on the discovery of the ideological delusion/haziness and on the "unmasking" of the ostensibly anticapitalist rhetoric, thus, ultimately, its concentration on the exposure of the deception of the (new) fascism. For the Left, though, the problem cannot be limited in the fact that the fascist ideology constitutes an instrument of deception concerning its real goals as such, a red herring that cover the real interests it waits upon, which are, of course, those of capitalism. For Ernst Bloch, this "revelatory" work is only too correct and useful - but it is not enough! The political work of the Left ought to also adopt as its target the "transcendent remainder" within the deception. It ought, in other words, to also search within the political claims of fascism the "shatter of an older and romantic opposition to capitalism" ingrained through

\footnotetext{
2 "Nazis sprechen betrügend, aber zu Menschen, die Kommunisten völlig wahr, aber nur von Sachen" (Bloch, 1935/1985, p.153).

3 "... denn was die Partei vor dem Hitlersieg getan hat, war vollkommen richtig, nur was sie nicht getan hat, das war falsch" (Bloch, 1935/1985, p.19).
} 552 
"deprivations of the present life" and with the longing for a hazy, vague "other"4.

The Left, as a rival in terms of its values political project, has the responsibility, the obligation to discern, to salvage, and to extract the positive heritage from within such an antithesis/resistance. This constitutes a prerequisite, to the extent that the Left would want to incorporate this positive heritage, this "shatter of a romantic opposition to capitalism", to its own political project that is based on values that are opposite to those of fascism.

Of course, the term 'heritage' here does not mean the hand-to-hand turning over of past generations' heirlooms to each new one. Heritage, as Ernst Bloch warns us, is not simply something that was accumulated in the past, but something that throws light on our horizons. This heritage throws light on the possibilities that are not (yet) clearly distinguished, illuminates, that is, all those that we can still anticipate. Tradition, though coming from the past, it nevertheless turns toward the future. The heritage projects a picture for the future on an already known landscape, so that it appears to us as something familiar, and, yet, it transcends the already known. Tradition is important to us, because it speaks to us as the "future within the past" and it "entrusts us with assignments" for our own particular future.

And even the viewpoint that is concerned with the "deception" is one that presupposes, (that is characterized by an unsaid acceptance of), the existence of something "positive" at first - which is, in fact, the reference point for the "deception". Besides, it was this "positive" that constituted the original motivation, which, in the course of time, became distorted. For the Left, the designation and the incorporation of this unfulfilled heritage is a powerful and at the same time painful lesson from the victory of the historical fascism.
Let us also not forget that the most highly charged concepts of fascism - "home", "land", "people" - are all multidimensional - though historically and value-wise not in the least neutral, but equivocal - "ciphers" (chiffres) for our multifaceted need and hope for the safety of our life, for safety in our life ${ }^{5}$. We will easily agree, I think, that clearly it is not the needs of people (of all people and not only "ours"!) for safety of, and security in their life that constitute, as such, a "problem". The search by people for an authentic community or the hope for the secureness of our life, for example, that are hidden in the fascist ciphers (chiffres) "home", "land", "people" are not dangerous and elusive. Elusive for the subjects themselves and dangerous for all the world are the answers offered by fascism, along with its relevant exhortations for action suggested to people for the satisfaction of their needs.

The Nazi - and not the Left - were those who gave a historically victorious political form and expression to the utopian substance included in the romantic anti-capitalism of specific social strata. The claims and demands of fascism were/are false and dangerous, but the "myths" behind them are not entirely "covered" by their abuse; they cannot be limited in their abuse. As we are reminded by Ernst Bloch: "The foundation of the non-synchronized contradiction is the unfulfilled fairytale of the good old times, the unresolved myth of the dark old Being or of Nature" ${ }^{\prime \prime}$.

The past that brings with it this myth, that carries this hope, is not going to end/go away for as long as its heritage will not have been salvaged and will not have been fulfilled for the present". We once more stress, however, that this "heritage" does not consist of folkloric happenings or elements

\footnotetext{
$\boldsymbol{\nabla} \nabla \nabla$

4 "Stück älteren und romantischen Widerspruchs zum Kapitalismus, mit Vermissungen am gegenwärtigen Leben, mit Sehnsucht nach einem unklar anderen" (Bloch, 1935/1985, p.16)

5 Of course, with the wider "existential" or social meaning of security, and not the limited one, as, for example, in its dimension referring to the police.

6 "Das Fundament des ungleichzeitigen Widerspruchs ist das unerfüllte Märchen der guten alten Zeit, der ungelöste Mythos des dunklen alten Seins oder der Natur" (Bloch, 1935/1985, p.122).

7 "... Bündnis, das aus Vergangenheit erst dadurch die in ihr noch mögliche Zukunft befreit, daß es beide in die Gegenwart setzt" (Bloch, 1935/ 1985, p.119)
} 
which can possibly be consumed as "objects", as "things" in the generalized competition that characterizes the capitalist logic and transforms everything in commodity. Contrary to such "synchronous" notion, synchronized, that is, with the dominant logic of capitalism, the "heritage" consists much more in the promise for the future, a promise that is contained, that is included by such elements. Such elements of an "unfulfilled past", "elements of an old society that have not yet died"8, are able to include pre- or anti-capitalist "promises" for our future. And in this way, they are transcendental, utopian, subversive elements vis-a-vis the objective and fully "synchronized" logic of the capitalist mode of production.

The acknowledgement of, on the one hand, the multidimensional and synthetic constitution of our social consciousness, and of the creativity of the political movements, on the other - with fascism included -, as well as our contradictory relationship with the past and the heritage that this past "hands over" to us, force us - as claimed by Ernst Bloch - to cultivate a "multilevel revolutionary dialects", one that will include many spaces and times and that will be able, in this way, to capture and carry questions and contents that "have not been outdone by the course of the economic development". The mill of such revolutionary dialectics will even be able to grind "non-rational contents" in order to salvage from within them the seed for the future.

Such a mill may also attempt the "dialecticalization" of the cornerstone of the new fascism, to attempt, that is, a dialectics of "nationalism from below". Here: with great emphasis to the fact that it concerns nationalism "from below". And this because nationalism "from above" is, both politically as well as in terms of its social origins and consequences, something completely different, thus needing also a completely different attempt for its conceptualization and analysis!
The nationalism from below is not simply an irrational remnant of the past that does not want to die and bedevils us from time to time as a nightmare or as a political zombie. Nationalism from below is possible to also include mystical and romantic pre- or anti-capitalist elements and references. For those "below!", nationalism receives its dynamics and its "persuasiveness" from and for the different at each time running societal processes (catchphrase: "transitional era"), and therefore constitutes an active, political, and up to date claim/ position in the reordering of societies - as an element for the reorganization of capitalism. It is in this where we find the "rational core" of the anticapitalist antithesis from the New Right, as opposition to the "neutral" commoditization of everything. Here, it is certain that the problem for the Left cannot be this opposition to capitalism, but, rather, the right perspective where this opposition is incorporated. The political perspective, that is, which has recruited this antithesis for the purpose of limiting and not broadening the solidarity so as to include all people - and not only those who are "ours" at each point in time.

What such a romantic anti-capitalism (as a possible element of nationalism) can propose as a better future is only a beautified picture of the past. As stressed by Ernst Bloch, the Nazi had a great appeal also because "the unbearable Now at least appears to be different with Hitler, who paints for all beautiful old things" 9 . It is in such a retouch of the picture of the glorious past with the gone-by grandeurs of each nation where the touts and the preachers of the new fascism have fixed their eyes. And the furthest away this glorious but also counterfeit past is, the more loud voices and fanfares are needed.

The non-rationalism of such a mystic and romantic opposition to capitalism, however, must not only be blindly ostracized and precluded as abstract and finite, but it ought to be analyzed in its historically specific association with the

\footnotetext{
8 "... Elemente alter Gesellschaft, welche noch nicht gestorben sind" (Bloch, 1935/1985, p.117).

9 "Auch die Massen strömten ihr zu, weil das unerträgliche Jetzt mit Hitler mindestens anders scheint, weil er für jedem gute alte Dinge malt" 554 (Bloch, 1935/1985, p.104).
} 
(proposed) "rationalism" of the capital as such, or, in other words, the most rational and effective transformation of everything into commodity. That is, the Left has to "salvage" the anti-capitalist, anticommercial elements/point and to incorporate them in its own political project of the generalized solidarity for all people and not only for those who are "ours" at each point in time.

Let us also not forget here that given the contemporary power relations, such a romantic "non-rationalism" expresses a few-member orchestra and is positioned across the thousands of members comprising the percussion orchestra of commoditization. Despite this, however, it constitutes the strongest echo against the ruffle of the capitalist rationality - as there is no stronger echo other than a Vibrant Left.

We can recapitulate the herein presented reflections in the following conclusions:

- Fascism cannot be a simple deception, because it is very difficult for a "mere deception" to be able to mobilize people;

- But it takes over true/real and unfulfilled needs and hopes - that as such constitute a resistance to the capitalist arrogance/logic of the commoditization of everything - and "gives" them a (fascist, barbarian) solution of its own;

- Consequently: our responsibility lies not in the rejection of these needs and hopes (which are basically needs and hopes for safety) - through the rejection of the distorted representations/ expressions of these needs. Our responsibility lies much more in the careful peeling of these needs/ hopes so as to take them out of their fascist wrapping;

- Exactly in order to become able to incorporate them in a left project, to give them, that is, a left answer (if we have a left answer, of course!).

\section{Nationalism from below as "political grief"}

Let us again turn our glance to the current reality of Greece. The accusation for "nationalism" is (still) a powerful weapon in Greece (and this became recently obvious in the notorious dispute about the history book distributed to the pupils of the last grade of elementary schools, in which history and its teaching method, as the fundamental aim of school textbook, were treated only as a minor issue). Toward the end of this article, I will make a short allusion, attempting a different reading of the current and "of great quantity" nationalism "from below" in Greece.

The intensive, emotionally charged (re)actions, manifestations of nationalism (from below) - either organized or spontaneous in the everyday transactions - bring to mind something that could possibly be conceptually perceived as "political grieve" for something that actually did not exist (as it was only an ideological project), but, despite its non-existence, it is now gone (or, so be it, has changed its semblance). In other words, it is about that painful feeling that I lost something, which, however, I never had.

This grieve does not concern something simply accidental or elusive, but something that (even as an ideological project!) contained "promise"; e.g., for social inclusion, for social mobility, for the materialization of some subjective/ individual plan (for one to start a family, to be distinguished as successful, to be recognized as normal, to belong somewhere, ...). With the radical societal changes of today (let us call it globalization, or something else ...), it is this "promise" that seems to be vanishing, even as a possibility, even on an imaginary level; it is this promise that seems to have died. (Thereof the strong reactions - given the endeared "rhetoric of complaints" in our country, the readiness for one to share their unease, to lay their head on someone's shoulder, let that shoulder belong to a prig or to a thug of the extreme right inside or outside the Parliament).

To this political grieve "from below" there comes to add extra tension and emotional charge that which is referred to as status fear in the European bibliography, that is, as the fear of the loss of the social status, as the fear of the loss of the social dues.

This tension acquires additional dynamic through the anger for the arrogance on the side of those who think (or so it is) that they have not missed the plane or the bicycle for the so called 
"globalized village", that is, on the side of those who have managed to "tether their donkey" in the central square of the said globalized village, and do not understand the rest who do not "detach" themselves from the past. It is self-evident that the scornfulness of the "successful" for the "behindhand" is not taken at all by the latter to be out of love or concern, it is not taken at all, that is, as an indication of solidarity with the "behindhand" on the part of the "successful".

To the overall tension there comes to contribute one more contradiction that had been created in a few past decades: The almost total transformation of the Greek political beings into individualized consuming entities (an unquestionable success of the great Change of Panhellenic Socialist Movement (PA.SO.K) in the 20 years of its governing Greece) clashes with the fact that in our cultural parallels grieve is a collective matter: practically, intellectually and emotionally. The individualized consumerist entity realizes, at one additional point in his/her life, that (s)he is isolated, is "alone" - something that perhaps does not create frictions in the lightsome hypostasis of the consumer as consumer, but it does create "burden" for someone who in his/her mourning relies traditionally on collectivities.

Moreover, the transformation into an isolated consuming entity did not occurred in and by itself as a phenomenon/evolution. In any case, it could not be realized without the active oblivion, the active erasure from the (individual and collective) memory of all those experiences and conceptualizations that form and shape the collective subjects. The active oblivion that was needed here must have been very intense, if one takes into consideration that there have been written off even the social practices of solidarity, the potential alternative forms of action, which were engraved on the collective memory in practice during the previous decades, and which the subjects were able to refer to.

In such a condition of isolation/loneliness, there appears to be easier for the subject-consumer to accept - as an answer/reaction - to respond to their (real or feared) insecurity with limiting solidarity to "our own race", "our own nation", "our own greekness" etc. To the extent, of course, that this subject-consumer is able to imagine or has been promised that it will be he/herself included in "our own race", "our own nation", "our own greekness". Such a (let it be imaginary) "mutual conscription" with those that will be "in" appears to be much easier and painless than the perception of the obvious/inherent limitations of this logic and of the - cognitive, emotional and practical - consequences that will ensue from such an intellectual encountering of reality.

It, therefore, appears easier for me to believe in a chimera - of "our own race", "our own nation", "our own greekness" - despite grasping continuously that the many TV channels which broadcast this Show simultaneously lose the signal of this chimera. Moreover, the political grieve owed itself to this fact of the "gradual dissolution" of such chimeras in the context of the hard societal reality. The chimeras, however, seem more reachable for one to complete his/her daily puzzle with his/her existential fragments than claiming the generalization of solidarity so as to include all the people.

And it is exactly in this "game" with the needs, the promises, the fantasies, the hopes, the fears, that is, with the subjective facets of the social issue, that there is a need for a Left which will neither fantasize nor proclaim the same chimeras only for the sake of not losing the contact with the "socially below" - as its electoral clientele. But also a Left that will not have exchanged the social issue, that is, the class struggle, with something more lightsome, liberal and digestible, as, for example, with the social mobility of its functionaries and members.

It is exactly in this "game" that there is a need for a Lively Left, one which will be taking seriously the historical responsibility that legitimizes its existence: to avert the savagery of fascism and to broaden solidarity extending it further and beyond those who are "our own".

\section{Reference}

Bloch, E. (1985). Erbschaft dieser Zeit. Berlin: Bibliothek Suhrkamp. (Original work published 1935).

Received: November 3, 2014 Approved: January 27, 2015 